\title{
Politics of Social Exclusion, State Reform and Security in Sri Lanka
}

\section{Sunil Bastian}

Abstract The general election in mid-1977 marked a turning point of Sri Lankan history. On the one hand, it marked the beginning of economic liberalisation and emphasis on the private sector as the engine of growth. On the other hand, representatives of the Tamil minority fought the election asking for a mandate to form a separate state. Making use of the two dimensions of capital - the realm of exploitation and surplus extraction, and that of coercion including state security - this article analyses the processes ensuring the social exclusion of large sections of the population and setting the stage for conflict. It argues that the current orthodoxies of state reform supported by the international community do not address issues of social exclusion and need to be rethought in order to avert violence and ensure long-term stability and security.

\section{Introduction}

The debate on security in Sri Lanka is dominated by the traditional discourse of the security of the state. Primacy is given to the question of how to ensure state security from internal as well as external threats. Notions such as human security have had very little impact on mainstream debates on security.

In recent times, these notions have consolidated even more. An obvious reason has been the separatist threat that the Sri Lankan state has been facing from Tamil ethno-nationalism. During the initial stages of Tamil self-assertion, the Tamil demand for a separate state was articulated through democratic means. But soon the Tamil political movement transformed into an armed conflict with the Liberation Tigers of Tamil Eelam (LTTE) becoming the dominant armed group. The LTTE developed into an armed organisation with infrastructural facilities resembling those of a regular militarised force. In addition to armed cadres, it developed capabilities in the sea and more recently in the air. It also styled itself as a regular armed force with ranks, insignia, etc. On top of this, the LTTE attempted to develop institutions resembling a state in the area where they were in control. These developments contributed to making the threat to state security a reality on the ground.
The Tamil struggle for separation internationalised very quickly, and the activities of the Tamil diaspora played a critical role in this process. The war forced a large section of the Tamil population to migrate and settle mainly in Europe, the USA and Australia. Over the years, this population became a formidable force in support of the separatist struggle. In addition, the Sri Lankan government has been under pressure from foreign governments and numerous international organisations to settle the conflict through negotiations. Among these governments, India, the regional power in South Asia, played a critical role. Finally, the overall context of globalisation within which the Sri Lankan state has had to operate has contributed to the internationalisation of Sri Lanka's conflict. Consequently, these factors enhanced the perception that the Sri Lankan state was under threat.

The main reaction to both these trends - the separatist challenge spearheaded by a militarised LTTE and pressure from forces emanating from outside the state - within Sri Lanka has been to strengthen the discourse of state security even more. This has been the dominant idea, especially within the majority Sinhala population and mainstream political parties. Currently, the Sri Lankan state, making 
use of these dominant sentiments, is waging a relatively successful military campaign against the LTTE.

Given this context, it is extremely difficult even to begin a discussion on new ideas of security. Many of the activities that are being conducted under the rubric of security sector reforms in this environment give the impression of being donor-driven projects that depend on the continuous interest of donors. The flipside of this comment is that these activities do not have a sufficient social and political base within the country so as to become an integral part of Sri Lanka's social transformation. There is a real danger that this type of activity could proliferate without a real contribution to the security of the population.

The central argument in this article is that if Sri Lanka is to begin a discussion on new ideas on security, discourse needs to be grounded in a range of issues that generate insecurity for the majority of the population. The dialogue needs to go beyond narrow technocratic ideas of security sector reform and focus on structures and processes that generate insecurity. As I shall argue in this article, this essentially means extending the current debates on state reform to include the question of social exclusion. Current debates on state reform focus on promoting a market economy, devolution of power in order to resolve the ongoing conflict and institutional design for depoliticising state institutions under the rhetoric of good governance. However, there is very little effort to address what all this means for the socially excluded. Rethinking state reform with social exclusion as a central concern is essential if state reform is to contribute to the stability and security of Sri Lankan society.

\section{Capital, coercion and social exclusion in post- 1977 Sri Lanka}

In his seminal work on state formation, Charles Tilly uses two categories: capital and coercion, to analyse different trajectories of European state formation. In his categorisation, capital occupies 'the realm of exploitation, where the relations of production and exchange themselves yield surpluses, and capitalists capture them' (Tilly 1992: 17). Coercion defines the realm of domination. 'The means of coercion centre on armed forces, but extend to facilities for incarceration, expropriation, humiliation and publication of threats' (Tilly 1992: 19). Although the trajectories of state formation in countries like Sri Lanka have a history different from that of the European experience, these two categories of capital and coercion, in the way they are defined by Tilly, are useful for understanding the nature of the state and social exclusion in contemporary Sri Lanka.

Our analysis begins in 1977. In the post-colonial history of Sri Lanka, the general election held in July 1977 was an important turning point. The centre-right United National Party (UNP) government, elected to power during that election, undertook a series of policy changes that shifted the Sri Lankan economy in a direction that gave emphasis to the markets, private sector and a greater degree of openness to the global economy. These were steps that were essential for strengthening capitalist relations in the economy and satisfying demands of capital.

However, this point also signified the deterioration of the relations between Sri Lankan Tamils and the Sri Lankan state. While the centre-right UNP, making use of their massive electoral victory in July 1977 to promote a plan to significantly shift the economy for the benefit of capital, the Tamil United Liberation Front (TULF), the principal electoral representatives of Tamils, contested the elections asking for a mandate from the Tamil people to form a separate state. This was a culmination of a series of developments, starting immediately after independence, which alienated the Tamil population from the Sri Lankan state.

These twin processes of trying to promote a capitalist economy on the one hand, and responding to Tamil demands for self governance on the other, have determined the dynamics of state reform and social exclusion in post-1977 Sri Lanka. It is essential to understand these two critical processes in order to promote a new discussion on state reform that takes social exclusion into account.

\subsection{Capital and social exclusion}

The demands of capital have brought about farreaching changes in the structure of the Sri Lankan state. The most important of them have been the establishment of a presidential system of government and a proportional representation 
system of elections to choose the legislature. The political objective of both these reforms was to manage the populist social pressures that are channelled through the legislature. Managing these pressures was essential to take forward the economic reform agenda. The presidency created a body that was elected directly, enjoying powers to take decisions on the economy independent of the legislature. The proportional representation system was expected to bring individual members of the parliament under the control of the party machinery to a greater degree than in the former electoral system where they had more autonomy (Bastian 2003; Wilson 1980).

Long before these reforms were implemented, the architect of these ideas, the first president of Sri Lanka, J.R. Jayawardena, argued the need for such reforms in order to carry out unpopular economic policies. His vision was one of a powerful presidency that could make critical decisions and create a stable parliament in which members could be controlled by the two main political parties (Jayawardena 1979). The political outcomes of both these steps have been different from what was envisaged. In other words, there was a clear gap between institutional design and the political outcomes. But a point to be emphasised is that one of the key objectives of the establishment of both these critical institutions that govern Sri Lanka today was furthering the interests of capital.

In addition to establishing totally new political institutions, Sri Lanka has undertaken a number of other reforms to reduce the role of the state in the economy. These are steps that have become familiar in many other parts of the world. The critical ones are reducing the interventionist role of the state in determining prices, privatisation of state-owned enterprises and opening up of the economy (Dunham and Abeysekera 1987; Lakshman 1997; Kelegama 2004; Sarvananthan 2005).

However, this reform process has not been smooth. Sections of the political class, bureaucracy, some of the left-oriented political groups and even ideologues of Sinhala nationalism have campaigned against state reforms. As a result some of the major reforms have not been carried out or have been implemented half-heartedly. For example, in 1987, a committee, established to bring about reforms in the public sector, published its findings and recommendations for reforms (Administrative Reforms Committee 1987). But very few of these recommendations have been implemented.

Similarly, there has been resistance against privatisation of a number of state-owned institutions, although this has been demanded both by local interests and international aid agencies. The Public Enterprise Reforms Commission (PERG), the body responsible for privatisation, was established in 1986. By the time it was dissolved in 2004, 98 state-owned ventures had been privatised. But there has been resistance to further privatisation. The critical areas that remain in need of some type of reform are the Ceylon Electricity Board, Ceylon Petroleum Corporation, Government Railways, state-owned roads and railway transport and state-owned banks.

Therefore, despite the dominance of marketoriented policies for the past three decades, the Sri Lankan state has not shrunk. In a report published in 1999, the World Bank declared that:

Sri Lanka's public sector is large, costly and suffers from low effectiveness and efficiency. With 12 percent of its labour force employed in the government in 1999 (17 percent if the semi-government sector is included), the country has the largest bureaucracy per capita in Asia. (World Bank 2000: 21)

Despite the limitations of the reform process and a more than two decade-old civil war, liberalisation of the economy has resulted in reasonable economic growth.

Sri Lanka has achieved three decades of sustained growth, averaging 4.9 percent annually since 1977 . In conjunction with modest population growth, this has resulted in doubling of the per capita incomes over the past two decades to over $\$ 1600$ in 2007. (World Bank 2008: 5)

In recent years, the growth has been robust: 7.7 per cent and 6.8 per cent in 2006 and 2007, respectively. The structure of the economy has undergone a shift away from the dominance of agriculture. Industry and services dominate the economy. Foreign exchange earnings are 
dominated by industrial exports and remittances from the global labour market.

Basically, the economy's performance shows that it has been opened up for capitalist accumulation and that the private sector has performed even in the midst of the intra-state conflict. A particular regional distribution of the economy has helped. Around half the gross domestic product (GDP) is concentrated in the Western Province close to the capital. The districts that cover the south-western quadrant of the country account for the bulk of the economic activities. This means that even if there is a war in the North/East, the economy could perform reasonably well if there was stability in these areas. Of course, there are opportunity costs of the war. If a peaceful settlement could be found, the performance of the economy would certainly be much improved.

On the social side, the country is displaying typical characteristics of societies where the impact of markets has become widespread. Despite numerous state as well as non-state interventions on poverty alleviation, consumption poverty was estimated to be around 23 per cent in 2002. This was estimated by the last Household and Income Survey - the official source for poverty measurement (World Bank 2007). However, this survey did not take into account the war that affected the North and East. Hence, it was likely that the poverty indicators should have been worse.

Inequality is as high as ever. The same Household and Income Survey of 2002 concluded that the highest two income deciles together account for more than half of the total income (53.7 per cent), while the lowest five deciles (i.e. the lower half of the total income deciles) account for only about one-fifth (19.6 per cent) of the total income (Central Bank of Sri Lanka 2003: 20).

The operation of markets and the shrinking proportion of agriculture in the economy signify a slow dismantling of rural livelihoods, especially in the smallholder paddy sector where the bulk of the rural population has been engaged. Even in households that are classified for the purposes of census as agricultural, a significant proportion of income comes from wage labour.

By contrast, there is significant growth of a wage earning class. Wage labour in sectors such as garments and plantations and migrant labour to the Middle East have become main sources of surplus and foreign exchange. The bulk of this labour is female. It is this working class that has been generating the surplus for maintaining a dysfunctional state and a costly war. Workers in the estates still operate under labour regimes characteristic of plantation production systems that depend on the availability of cheap labour. In many Middle Eastern countries, labour rights are almost non-existent.

In short, although market economies are spreading rapidly, the record of various strategies to tackle social contradictions is very weak. Safety nets have not worked. However much there has been a proliferation of non-state sector activities promoted by donors interested in tackling these issues, they have not been successful. Pro-poor growth, inclusive growth or the other fashionable terms that donors employ do not seem to provide solutions.

The real problem of Sri Lanka in the area of social exclusion has been the inability of a bloated and dysfunctional state to intervene on behalf of the socially excluded in the context of penetration of capitalist production relations. This has been largely due to the undermining of state capacity through patronage politics.

Since the period of liberal economy, ideological differences between the two main parties on economic policies have disappeared. In their place has appeared a system of patronage politics, where politicians seek power mainly to ensure access to resources and influence that state power provides. In this politics, the state has become a means of accumulation as well, dolling out patronage to supporters. Devoid of ideological underpinnings, politicians move from party to party in search of these opportunities to access state power.

The particular proportional representation (PR) system that has been instituted has complicated this trend. Instead of the stability envisaged by the designers of PR, what have prevailed are coalition governments and frequent crossovers. Therefore, in order to ensure stability of regimes both coalition partners and various fractions of ruling parties have to be satisfied. The outcome has been jumbo-sized cabinets and proliferation of state institutions. For instance, in 1999 there 
were 35 government ministries (World Bank 2000: 21). At one time, the current administration had 26 cabinet ministers, 26 noncabinet ministers and 18 deputy ministers, making a total of 70 ministers. There has not been any significant reduction from these levels.

The biggest impact of this undermining of the state has been on those sectors of the state that are in charge of the delivery of social and welfare services. In other words, while those parts of the state responsible for promoting interests of capital have functioned with some degree of coherence, institutions responsible for taking care of the socially excluded have been undermined.

In the absence of an effective state that can intervene on behalf of the socially excluded, organised action on behalf of these groups has not resulted in many benefits. Sri Lanka has a long tradition of trade unionism. Some of the trade unions, especially in the plantation sector, are still active and sometimes effective. But there are many trade unions caught up in the cancer of patronage politics. However, there is a large section of the working class that is not unionised. Further, Sri Lanka never had a peasant movement that made a lasting mark on the country's politics. ${ }^{2}$ Many of the more recent civil society interventions have had the character of being isolated projects rather than attempts to develop social movements that can influence state policies.

\subsection{Coercion and social exclusion}

Alienation of the Tamil population from the Sri Lankan state has been the most significant dimension of social exclusion. The post-1977 period has been characterised by the worsening of this relationship and a civil war. The record of institutional reforms to meet the grievances of the Tamil population during the same period has been dismal. The only significant reform has been the enactment of the 13th amendment to the constitution in 1987, which established the system of provincial councils with a certain degree of devolved powers. However, the primary mover in enacting these reforms was India and not the Sri Lankan political class. The 13th amendment was the result of several years of pressure from India, starting from 1983. After agreeing to implement the constitutional amendment and establish provincial councils, the Sri Lankan political class has undermined implementation at every turn. The first provincial council in the combined North/East Province, which was the focus of the Tamil's demand for autonomy, lasted less than five months. From this point onwards, there has been no elected provincial council in the North/East. The current administration, while waging a military campaign against LTTE, has carried out elections for the Eastern Provincial Council, which has been separated from the combined North/East council. However, whether this council will gain legitimacy among the Tamil population, and whether it will be an answer to Tamil grievances, remains to be seen.

In the meantime, the coercive side of the Sri Lankan state has been strengthened to meet the armed threat from the LTTE. This has brought far-reaching changes to Sri Lankan security structures. On one hand, with its largely ceremonial army, the military has become a formidable force with an increased strength in numbers as well as equipment. It has grown to a force of approximately 115,000 personnel that absorbs 4.5 per cent of the GDP. ${ }^{3}$ On the other hand; it is also operating within an institutional framework that, comparatively, gives it much more power.

Formally, the security forces are under civilian control. Constitutionally, they are placed under the Minister of Defence. Normally, this post is occupied by the executive - earlier the prime minister and now the president. The president controls security forces through the Ministry of Defence. Usually the secretary to the Ministry of Defence is a loyal bureaucrat. This has become a strategy through which the political class controls the security forces.

According to the constitution, the security sector is accountable to parliament. But the degree to which parliamentary mechanisms are utilised to oversee the security sector is marginal. The consultative committee in parliament dealing with security forces is ineffective. Even when the security forces become the subject of parliamentary discussions, such as at the time of budgetary discussions, there is very little scrutiny of the security institutions.

This situation has been made worse by the enactment of laws, which have enormously expanded the powers of the security forces 
without mechanisms for accountability. For example, starting from the early 1970 s, when the Sri Lankan state began to face violent challenges, emergency regulations have become the norm, rather than the exception. While having formal structures of democratic rule, Sri Lankans have lived under emergency rule for the last three decades. In addition to this, Sri Lanka has passed draconian laws like the Prevention of Terrorism Act in 1979 and Prevention and Prohibition of Specified Terrorist Activities Regulation. These legislative enactments have undermined human rights and created a climate of impunity.

The activities of the coercive side of the state and of various armed groups on the Tamil side have had a devastating impact on the population. The bulk of this impact has been on the Tamil population in general and those living in the Northern and Eastern Provinces in particular. This has been recorded in numerous reports compiled by human rights organisations, local as well as foreign ${ }^{4}$ and includes the entire catalogue of atrocities such as deaths, disappearances, unlawful detentions, arrests, torture, etc. There is now an entire generation of people traumatised by war. Hundreds of thousands have been displaced, sometimes several times. The impact of the social and economic infrastructure has been significant, contributing, along with the other factors, to the exclusion of a significant section of the population. Some have escaped these conditions by migrating out of the war zone. Others, mainly the poorer sections, have continued to survive in the war-torn area mainly through the support of humanitarian agencies.

Thus, the twin processes of penetration of capitalist relations and action of the coercive apparatus of the state have resulted in a condition of insecurity for a large section of the population. In both these dimensions, changes that have taken place within the structure of the state have been critical. When it comes to the arena of capital, while the state has been reformed to promote the interests of capital, it has not been to been able to protect the socially excluded from the negative impacts of the market. On the coercive side, while the state has undertaken a determined military effort to crush the separatist armed groups, there have been few institutional reforms to meet the grievances of the Tamil population.

\section{Rethinking state reform}

The critical issue facing the Sri Lankan polity in the context of widespread insecurity due to the spread of capitalist relations and the impact of coercive action of the state is how to move beyond current orthodoxies of state reform. Such orthodoxies of state reform do not possess the fundamental ingredients necessary for tackling the issue of social exclusion.

The current orthodoxies of state reform have the following three elements:

1 Continued reform of the state to promote a market economy

2 Devolution of power as a response to the Tamil demand for autonomy

3 Institutional design to promote good governance.

Continuation of the state reforms for promoting a market economy is a discourse that is promoted by many actors, such as mainstream economists, business interests and major donors. This has been a primary objective of policy-based lending under structural adjustment. Donors have withdrawn funding when these reforms were not carried out. But this strategy does not include any serious ideas for tackling the problem of social exclusion.

The second area, that of devolution, has been dominated by constitutional lawyers.

Consequently, there has been a seemingly endless discussion about various devolution models found in different parts of the world and the letter of the law. An incredible amount of energy has gone into this question without the actors asking what it means for the socially excluded. This is not to argue against devolution. At least the majority of the Tamil population would welcome it as a concession to their demands. So much blood has flowed that it is very difficult to foresee a solution that satisfies the Tamil population without some form of genuine devolution, and the Sinhalese will probably accept it if it brings peace to the country.

However, if devolution is to be something more than an effort that consolidates the power of the elite in the periphery, the discussion has to go beyond the debate on institutional design, as at present. The mere crafting of a new institution within the entrenched structures of power does not do much to improve the lot of the socially 
excluded. Empirical work in areas where provincial councils currently exist will show this. In many instances, what has happened is to create a new vehicle of power for the peripheral elite. What is more, the political objective of many of these elites seems to be how to utilise the provincial system in order to climb the ladder to the centre.

Similar comments can be made on the third and final area of state reforms - institutional design to take care of issues such as politicisation of state apparatus, accountability of state institutions and impunity of security forces. It is clear that many years of institutional design have not had desired results on the ground.

Sometimes those in power have totally ignored these institutions or they have been captured by vested interests, rendering them ineffective. It is pretty clear that the internal logic of the institutional design itself will not deliver the expected results.

Historical examples show that institutions that are meant to regulate the behaviour of the state become effective when social groups affected by the institutions get organised and begin to make use of them. The trade union movement of Sri Lanka is a good example. It became effective not only because new legislation conducive to its establishment was passed in the mid-1950s, but also because organisations were built making use of the space created by institutional reform. Without this element, these exercises of institutional design have the characteristics of a top-down approach and become a pastime of the elite. There are many civil society efforts in campaigning for these reforms, monitoring them or carrying out training programmes about them. On the other hand, there are hardly any efforts to explore the links between these institutions and self-organisations of the socially

\section{Notes}

1 There is a significant volume of literature covering various dimensions of this issue. For an interesting recent contribution, see Nira Wickramasinghe (2006).

2 See Moore (1985) for discussion of peasant politics in Sri Lanka. excluded that could benefit from them or promote such forms of self organisation.

The period of negotiations under the United National Front (UNF) government conducted during 2002-3 was a period when these ideas enjoyed hegemony in the country. Continued reform of the state to promote a market economy, devolution through negotiations with LTTE and good governance were the ideological underpinnings of the UNF-led peace process. They had strong support from the regime that was in power, international aid agencies and civil society actors who had been receiving international assistance. It was the period of triumph of existing orthodoxies of state reform.

The defeat of the UNF government in the general elections of April 2004 demonstrated a major flaw in this set of ideas. The UNF's defeat was largely due to the voting pattern of the Sinhala electorate. There is no doubt that one of the contributing factors to its defeat was the complete absence of any ideas to tackle social exclusion through economic reforms while taking steps to promote the interest of capital. The combination of this discontent, coupled with the ideology of Sinhala nationalism, which opposed negotiations with the LTTE, brought about the UNF's defeat. The missing ingredient was ideas for state intervention so that the socially excluded could benefit from a globalised market economy.

To conclude, what we have tried to argue is that the current orthodoxies on state reform have not explored the links between these reforms and the interests of the socially excluded. If this is taken into account, there is room for expansion of these debates. In our view, this is essential if the current debates are to contribute towards social stability and security.

3 Institute for Peace and Conflict Studies, www.ipcs.org

4 Perhaps the best recording of the plight of the Tamil population has been done by the University Teachers for Human Rights (Jaffna), www.uthr.org 


\section{References}

Administrative Reforms Committee (1987), Administrative Reforms - An Agenda for Action, Report No. 1, Sessional Paper No. VIII, Colombo: Government Publications Bureau

Bastian, Sunil (2003) 'The Political Economy of Electoral Reform: Proportional

Representation of Sri Lanka', in Sunil Bastian and Robin Luckham (eds), Can Democracy be Designed, The Politics of Institutional Choice in Conflict-Torn Societies, London: Zed Books

Central Bank of Sri Lanka (2003) Annual Report, Colombo: Central Bank of Sri Lanka

Dunham, David and Abeysekera, Charles (eds) (1987) Essays in the Sri Lankan Economy 1977-83, Colombo: Social Scientists Association

Jayawardena, J.R. (1979) Selected Speeches and Writings, Colombo: Jayawardena Centre

Kelegama, Saman (ed.) (2004) Economic Policy in Sri Lanka, Issues and Debates, Colombo: Vijitha Yapa Publications

Lakshman, W.D. (ed.) (1997) Dilemmas of Development, Colombo: Sri Lanka Association of Economists
Moore, M. (1985) State and Peasant Politics in Sri Lanka, Cambridge South Asian Studies, Cambridge, Cambridge University Press Sarvananthan, Muthukrishnan (ed.) (2005) Economic Reforms in Sri Lanka, Colombo: International Centre for Ethnic Studies Tilly, Charles (1992) Coercion, Capital and European States AD 990-1992, Oxford: Blackwell Wickramasinghe, Nira (2006) Sri Lanka in the Modern Age: A History of Contested Identities, Colombo: Vijitha Yapa Publications

Wilson, A.J. (1980) The Gaullist System in Asia, London: Macmillan

World Bank (2008) Sri Lanka Country Assistance Strategy 2009-2012, Washington DC: World Bank

World Bank (2007) Sri Lanka Poverty Assessment, Washington DC: World Bank

World Bank (2000) Sri Lanka, Recapturing Missed Opportunities, Washington DC: World Bank 